Original article

\title{
Nanoscale Zerovalent Iron Based Moderation of Chromium Stress in Tomato Seedlings is Related with Induced Antioxidants and Suppressed Cr Uptake
}

\author{
Syeda Iqra Batool (i) a, ", Muhammad Dawood (i) a, Muhammad Nawaz (i) a \& Zaffar Malik (i) b \\ a Department of Environmental Sciences, Bahauddin Zakariya University, Multan, Pakistan \\ ${ }^{b}$ Department of Soil Science, University College of Agriculture and Environmental Sciences, Islamia University of Bahawalpur, Bahawalpur, Pakistan
}

\begin{abstract}
The nanoscale zerovalent iron (nZVI) has been widely used in remediation of environmental pollutants from the aqueous as well as soil media. The present study was conducted to evaluate the role of $n Z \mathrm{VI}$ as a soil amendment in amelioration of chromium (Cr) toxicity in tomato seedlings. Three weeks exposure with low (10 mg kg-1) and high (100 mg kg-1) $\mathrm{Cr}(\mathrm{VI})$ was given to tomato seedlings grown in soil medium supplemented with or without $500 \mathrm{mg} \mathrm{kg-1} \mathrm{nZVI} \mathrm{in} \mathrm{corresponding} \mathrm{soils.} \mathrm{The} \mathrm{Cr}$ exposure greatly reduced the biomass with high $\mathrm{Cr}(\mathrm{VI})$ lowering the plant height, root length, shoot and root biomass by $34,24,33$ and $49 \%$, respectively. However, nZVI significantly restored the growth retardation by increasing these parameters by $17,14,19$ and $33 \%$, respectively. The $\mathrm{nZVI}$ also lowered the $\mathrm{Cr}$-induced MDA content, improved membrane stability index and increased relative water contents. The nZVI was also effective in improving the chlorophyll pigments and carotenoids contents. The antioxidant enzymes (viz. SOD, POD, CAT and APX) were slightly increased by $\mathrm{Cr}$ stress. The nZVI application together with $\mathrm{Cr}$ stressed soil further enhanced these enzyme activities. Application of $\mathrm{nZVI}$ further lowered the significant amount of $\mathrm{Cr}(\mathrm{VI})$ in shoots and roots tissues. The nZVI-induced tissue $\mathrm{Cr}$ concentration was lowered by 35\% in shoots in case of low $\mathrm{Cr}$ exposure and $29 \%$ in roots by high $\mathrm{Cr}$ treatments. The amelioration of $\mathrm{Cr}$-induced toxicity in tomato seedlings by $\mathrm{nZVI}$ application in soil seems to be the result of suppression of $\mathrm{Cr}$ uptake and enhancement in antioxidant enzyme system.
\end{abstract}

Keywords: nZVI, ROS, Antioxidant, Chromium, Tomato, Oxidative Stress, Biomass.

Received:06 December $2021 \quad$ * Accepted:14 December 2021 * DOI: https://doi.org/10.29329/ijiaar.2021.415.5

\footnotetext{
* Corresponding author:

Muhammad Dawood, Department of Environmental Sciences, Bahauddin Zakariya University, Multan, Pakistan. Email:drdawood@bzu.edu.pk
} 


\section{INTRODUCTION}

Human activities and industrial processes have led to the contamination of natural media including the soil and water, thus posing great threat to agricultural crops and human health via entry of the pollutants into food chains. The so called "heavy metals" are the potential toxic elements (PTEs) which originate from fossil fuel burning, municipal and industrial wastes, agricultural inputs and the sewage water; and make their way into agricultural soils and water thus limiting crop production and deteriorating quality of food crops (Malik et al., 2021; Oh et al., 2007). Among the most prevailing PTEs, chromium (Cr) is ranked $7^{\text {th }}$ among the top 20 hazardous chemicals and the top most among carcinogenic PTEs (Oh et al., 2007). The hexavalent chromate $\mathrm{Cr}(\mathrm{VI})$ and the trivalent chromite $\mathrm{Cr}(\mathrm{III})$ are the most common and stable forms found in the natural environment (Ashraf et al., 2017). Due to its carcinogenicity, mutagenicity and teratogenicity nature, the $\mathrm{Cr}(\mathrm{VI})$ form is more mobile and toxic to biological processes. The researchers around the globe are particularly concerned about the environmental pollution of $\mathrm{Cr}(\mathrm{VI})$ because of its ever increasing levels in the water and soil media originating from natural and anthropogenic activities including metallurgical, refractories and chemicals processes (Ashraf et al., 2017; Z. Malik et al., 2021). In humans, Cr(VI) toxicity creates serious diseases including the nervous system disorder, renal failure, hematopoietic abnormalities and gastrointestinal diseases (Zeng et al., 2011). Cr(VI) toxicity also exerts various impairments in plants thus hampering the normal development and metabolism. It deteriorates the plant growth, imbalances in nutrient uptake and photosynthesis, induces synthesis of reactive oxygen species (ROS) and causing lipid peroxidation, and alters the antioxidant enzymatic and non-enzyme activities (Noli \& Tsamos, 2016; Shaheen et al., 2016; Zeng et al., 2011). More importantly, Cr(VI) after entering into plant system accumulates in edible plant parts and thus poses severe health hazards for the ultimate consumers (Cherfi et al., 2015). Toxicity of $\mathrm{Cr}$ in biological processes of the plants and associated alteration in physiological activities relies directly on the concentration of $\mathrm{Cr}$ uptake by plant roots, its translocation to aboveground plant parts, and the accumulation in fluorescent tissues (Singh et al., 2021).

At cellular levels, $\mathrm{Cr}(\mathrm{VI})$ induces the synthesis of ROS leading to oxidative damage which can be indicated by overproduction of malondialdehyde (MDA), cellular membranes permeability and electrolyte leakage (EL) (Patra et al., 2019; Yu et al., 2018). The accumulation of ROS ultimately leads to the peroxidation of membrane lipids and disruption of membrane structure and function, which further causes the oxidation of cellular proteins and nucleic acids (Wakeel et al., 2020). Plants like other living organisms have evolved antioxidant system mainly comprising of superoxide dismutase (SOD), peroxidase (POD), catalase (CAT), and ascorbate peroxidase (APX). These antioxidant enzymes detoxify the deleterious effects of ROS overproduction and confer the plants resistance against variety of stressful conditions (Zaheer et al., 2020). Here, it is worth mentioning that Cr toxicity also exerts negative impacts on the plants natural antioxidant defense system However, Cr toxicity also affects the 
activities of the enzymes (Wakeel et al., 2020). Generally, higher Cr(VI) accumulation severely alter the plants structural, biochemical and physiological functioning of plants including the photosynthetic performance and ultimately results in poor production and yield decline (Singh et al., 2020).

Various remediation strategies have been being investigated for last two decades to clean up the soils from Cr pollution or at least limiting its entry into crop plants. These strategies include the chemical reduction of $\mathrm{Cr}(\mathrm{VI})$ to $\mathrm{Cr}(\mathrm{III})$, solvent extraction, chelation, absorption and adsorption (Li et al., 2019; Mitra et al., 2017). More recently, zerovalent iron nanoparticles (nZVI) have been employed successfully to clean up the contaminated media including the $\mathrm{Cr}(\mathrm{VI})$ due to their excellent removal potential of variety of pollutants from aqueous solutions as well as soil medium. The nZVI are the coreshell structures, where the core is generally made up of metallic iron while the shell is composed of Fe(II) and Fe(III) oxides and hydroxydes (Vilardi et al., 2018). The nZVI mediated removal/reduction of $\mathrm{Cr}(\mathrm{VI})$ has been investigated by various researchers (Di Palma et al., 2015; Vilardi et al., 2019). The nZVI are highly effective to adsorb, interact with, or reduce a variety of pollutants including the aromatic and chlorinated pollutants, and heavy metals (Yuvakkumar et al., 2011).

Not much work has been done in the area of effects of nZVI on plant growth performance under environmental stressful conditions. Recently, it has been shown that nZVI application increased the carotenoids contents, chlorophyll pigmentation and photosynthetic performance in tomato plants (Brasili et al., 2020). Though nZVI have been highly effective in remediating the pollutants from soil and water media, its impact on plant physiological and biochemical processes has yet to be investigated. The current study focusses on investigating the potential of nZVI as a soil amendment for alleviation of $\mathrm{Cr}(\mathrm{VI})$ toxicity in tomato plants. Tomato is one of the most important food crop mainly grown in suburban areas receiving a plenty of sewage water which normally has high amounts of Cr. Application of nZVI in Cr-contaminated agricultural fields can be a sustainable approach for healthier and optimum crop production of tomato.

\section{MATERIAL and METHODS}

\section{Soil Preparation and Experimental Set up}

The study comprised of a pot experiment, which was performed at the botanical garden of Bahauddin Zakariya University Multan, Pakistan. The sandy loam soil was collected from the agricultural farm of the university and prepared according to standard procedures required for the study. Before artificially spiking with $\mathrm{Cr}(\mathrm{VI})$, the soil was well dried, ground and sieved inorder to remove physical impurities. For artificially contamination with $\mathrm{Cr}(\mathrm{VI})$, the soil was spiked with two levels of $\mathrm{Cr}(\mathrm{VI})$ namely $10 \mathrm{mg} \mathrm{kg}^{-1}$ dry weight as low dose of $\mathrm{Cr}$, and $100 \mathrm{mg} \mathrm{kg}^{-1}$ dry weight as high dose of $\mathrm{Cr}$. The salt of potassium dichromate $\left(\mathrm{K}_{2} \mathrm{Cr}_{2} \mathrm{O}_{7}\right)$ was used as the source of $\mathrm{Cr}(\mathrm{VI})$. Required doses of $\mathrm{Cr}(\mathrm{VI})$ were dissolved in deionized water and subsequently mixed in respective treatments by mixing the 
required $\mathrm{Cr}(\mathrm{VI})$ dose in equal amounts of water. The same amount of water was applied to control soils having no $\mathrm{Cr}(\mathrm{VI})$ and nZVI alone soils. After mixing the $\mathrm{Cr}$ solution into respective soils, these were kept drying for week. On subsequent week, the soils were again irrigated and well mixed followed by another spell of drying. A total of 4 cycles of soil spiking were carried out in order to make the $\mathrm{Cr}$ well mixed and uniformly distributed in respective soil treatments. After incubation and $\mathrm{Cr}$ spiking, the respective treatments were supplemented with nZVI at the rate of $500 \mathrm{mg} \mathrm{kg}^{-1}$ soil. The nZVI was very kindly obtained by the soil science department of The Islamia University Bahawalpur, Pakistan, where it was synthesized by green synthesis process using mango peel. The selection of low and high levels of $\mathrm{Cr}\left(100\right.$ and $\left.100 \mathrm{mg} \mathrm{kg}^{-1}\right)$ and level of nZVI $\left(500 \mathrm{mg} \mathrm{kg}^{-1}\right)$ was made as per our preliminary experiments (not published yet). After supplementation with nZVI, the soil sets were again irrigated and kept for drying before loading into respective pots for the performing of experiment in glasshouse. The experiment contained five treatments and a control for normal conditions having no $\mathrm{Cr}$ or nZVI supplementation. The nZVI alone treatment was meant to evaluate any harmful impact upon tomato seedlings. While four treatments included the solo application of low and high doses of $\mathrm{Cr}(\mathrm{VI})$ as well as with the supplement of nZVI with both these Cr levels. The equal amounts of well pulverized soils $(7.5 \mathrm{~kg})$ as per respective treatments were loaded in plastic containers. Tomato seedlings were grown in separate trays containing peat moss; and uniform healthy seedlings ( 7 days post germination) were transplanted into plastic pots and immediately irrigated with equal amounts of water. All the pots were supplemented with half strength NPK solution to meet the basic nutrient requirements of the plant. All the treatments were replicated with three replication, each having five plants per pot. The young seedlings were kept growing for three weeks followed by measuring growth parameters and tissue sampling for biochemical analyses. The experiment was carried out in glasshouse uniform conditions with $16 / 8 \mathrm{~h}$ day/night length and $30{ }^{\circ} \mathrm{C} / 25{ }^{\circ} \mathrm{C}$ day/night temperature, $85 \%$ relative humidity, and $400 \pm$ $25 \mu \mathrm{M}$ photons $\mathrm{m}^{-2} \mathrm{~s}^{-1}$ light intensity, which was measured daily at the top of plant canopy by a portable light meter (Li-250 A; Li-Cor, Lincoln, NE, USA).

\section{Estimation of Plant Biomass}

After three weeks of growth, plant heights were recorded using a normal scale. The SPAD (soilplant analyses development) value was recorded by using SPAD meter (SPAD-502, Zhejiang Top Instruments Co., Ltd., China) on the topmost second fully opened leaf. The plants were carefully uprooted from the pots without harming the roots in fully wet conditions. After measuring root lengths, these were cut into roots and shoot tissues. For estimation of membrane stability index, relative water content, MDA and antioxidant enzymes, top $2^{\text {nd }}$ fully opened leaves were separated and used for biochemical assays accordingly. The roots and shoots (stem and leaves) were kept for oven drying before acid digestion and estimation of Cr contents. 


\section{Plant Tissues Chromium Determination}

For measurement of $\mathrm{Cr}$ concentration in shoot and root tissues, freshly harvested seedlings were washed thoroughly with water followed by 20 min immersing in $20 \mathrm{mM}$ EDTA solution in order to clean it from any adsorbed metal ions on plant surfaces. Separated shoots and roots were oven dried at $80{ }^{\circ} \mathrm{C}$ for 24 hours. After grinding about $1.0 \mathrm{~g}$ plant material was digested with $\mathrm{H}_{2} \mathrm{SO}_{4}$ and $\mathrm{H}_{2} \mathrm{O}_{2}$. Finally, the $\mathrm{Cr}$ contents in shoots and roots tissues was measured by atomic absorption spectrophotometer (Shimdazoo AA 6300) (Malik et al., 2021).

\section{Estimation of Relative Water Content, Membrane Stability Index and MDA Content}

The relative water contents (RWC) of the leaves was measured according to the method described by Lazcano-Ferrat and Lovatt (1999). Briefly, the youngest leaf of tomato plants kept sealed in plastic bags and quickly transferred to the laboratory. After noting the fresh weight (FW) by using simple electrical balance, the turgid weight (TW) was recorded after soaking the leaves in distilled water for 24 $\mathrm{h}$ at room temperature. Finally, the dry weight (DW) was measured after drying at $65^{\circ} \mathrm{C}$ for $72 \mathrm{~h}$. For calculation of RWC, following equation was used:

$$
\mathrm{RWC}(\%)=(\mathrm{FW}-\mathrm{DW}) /(\mathrm{DW}-\mathrm{TW}) \times 100
$$

For determination of Membrane stability index (MSI), $0.1 \mathrm{~g}$ of the leaf discs were crushed, followed by $30 \mathrm{~min}$ heating in $10 \mathrm{ml}$ distilled water at $40{ }^{\circ} \mathrm{C}$. Firstly, initial electrical conductivity $\left(\mathrm{C}_{1}\right)$ was determined by electrical conductivity (EC) meter and then the electrical conductivity $\left(\mathrm{C}_{2}\right)$ was recorded by keeping the same sample for $10 \mathrm{~min}$ in water bath at $100{ }^{\circ} \mathrm{C}$ (Sairam et al. 2002). The MSI was calculated using the following Eq. (2):

$$
\mathrm{MSI}=\left[1-\left(\mathrm{C}_{1} / \mathrm{C}_{2}\right)\right] \times 100
$$

Chlorophyll $\mathrm{a}$ and $\mathrm{b}$ and carotenoid contents were measured as per the methods described by Arnon (1949) and Wellburn (1994), respectively. Briefly, $0.05 \mathrm{~g}$ fresh leaf material was ground in mortar. After extraction in $10 \mathrm{ml}$ dimethylsulphoxide (DMSO), these samples were kept for $4 \mathrm{~h}$ in oven at $65^{\circ} \mathrm{C}$. After heating, the absorbance of extract was recorded by spectrophotometer (Halo DB-20/DB20S, Dynamica Company, London, UK) at $645 \mathrm{~nm}, 665 \mathrm{~nm}$ and $470 \mathrm{~nm}$ for chlorophyll a, chlorophyll $\mathrm{b}$ and carotenoid contents, respectively. Extinction constants and equation were used to finally calculate the respective chlorophyll and carotenoid contents. For MDA contents determination in shoots/leaves, $0.5 \mathrm{~g}$ fresh leaf samples were ground in $10 \mathrm{ml}$ TBA solution $(0.25 \%)$, already prepared in trichloroacetic acid (TCA) (10\%). The extracted material was heated at $95{ }^{\circ} \mathrm{C}$ for $30 \mathrm{~min}$, followed by ice-cooling to stop the reaction. After 10 min centrifugation at $10,000 \mathrm{~g}$, the absorbance of supernatant's absorbance was noted at $532 \mathrm{~nm}$. A simultaneous absorbance at $600 \mathrm{~nm}$ was also taken, which was then subtracted 
for correction of non-specific turbidity. Finally the MDA content in leaves/shoots was determined by using $155 \mathrm{mM}^{-1} \mathrm{~cm}^{-1}$ as extinction coefficient (Ali et al., 2018).

\section{Estimation of Antioxidant Enzymatic Activity}

For antioxidant enzymes extraction, plant leaves/shoots were firstly rinsed with distilled water. After that, plant extract ( $0.5 \mathrm{~g})$ was placed on chilled plaster. The phosphate buffer solution ( $\mathrm{pH}$ of 7.8 ) of about 2-3 $\mathrm{ml}$ was added, followed by distilled water addition to make the final volume of $1000 \mathrm{ml}$. a $5 \mathrm{ml}$ buffer solution was added to make the samples homogenized. After centrifugation (8000$13,000 \mathrm{rpm}$ ) for $20 \mathrm{~min}$ at $4{ }^{\circ} \mathrm{C}$, resultant supernatants were placed in $5 \mathrm{ml}$ centrifuge tubes. The activities of antioxidant enzymes were measured by spectrophotometer (Halo DB-20/DB-20S, Dynamica, UK). The SOD activity determination was done by homogenizing $100 \mu$ l enzyme extract in $3 \mathrm{ml}$ reaction mixture which had $50 \mathrm{mM}$ potassium phosphate buffer ( $\mathrm{pH} 7.8$ ), $75 \mu \mathrm{M}$ nitro-blue tetrazolium (NBT), $2.0 \mu \mathrm{M}$ riboflavin, $13 \mathrm{mM}$ methionine and $0.1 \mathrm{mM}$ EDTA. Activity was recorded at $560 \mathrm{~nm}$, (Zhou et al., 1997). The POD activity of was assayed according to Zhang (1992) with minor modifications. For POD activity, the reaction mixture contained of potassium phosphate buffer ( $\mathrm{pH}$ 7.0) $(50 \mathrm{mM})$, guaiacol (1\%), $\mathrm{H}_{2} \mathrm{O}_{2}(0.4 \%)$ and enzyme extract $(100 \mu 1)$. The activity was recorded at $470 \mathrm{~nm}$ absorbance at. For the activity of CAT was assayed in reaction mixture $(3 \mathrm{ml})$ having potassium phosphate buffer (pH 7.0) $(50 \mathrm{mM})$, EDTA-Na $2(2 \mathrm{mM}), \mathrm{H}_{2} \mathrm{O}_{2}(10 \mathrm{mM})$ and enzyme extract $(100 \mu \mathrm{l})$. The CAT activity was measured with the use of $\mathrm{H}_{2} \mathrm{O}_{2}$ (as extinction coefficient) for 1 min at A240. In case of APX activity, reaction mixture $(3 \mathrm{~mL})$ was consisted of phosphate buffer $(\mathrm{pH} \mathrm{7})(100 \mathrm{mM})$ EDTA-Na $2(0.1 \mathrm{mM})$, ascorbic acid $(0.3 \mathrm{mM}), \mathrm{H}_{2} \mathrm{O}_{2}(0.06 \mathrm{mM})$ and $100 \mu \mathrm{L}$ enzyme extract. The change in absorption was taken at $290 \mathrm{~nm}$ for $30 \mathrm{~s}$ after $\mathrm{H}_{2} \mathrm{O}_{2}$ addition (Nakano and Asada, 1981).

\section{Statistical Analysis}

All the data were subjected to one-way analysis of variance (ANOVA). Statistical difference among treatments were determined by Duncan's multiple range test by using SPSS17.0 statistical package at probability level $\mathrm{p}<0.05$ (SPSS. Chicago, IL, USA).

\section{RESULTS}

\section{Effect of nZVI on Plant Biomass under Cr Stress}

Biomass of the tomato seedlings was severely affected by 3 weeks exposure to $\mathrm{Cr}(\mathrm{VI})$ in nutrient medium. Plant height was reduced by $21 \%$ and $33 \%$ by exposure to low $\mathrm{Cr}\left(10 \mathrm{mg} \mathrm{kg}^{-1}\right)$ and high $\mathrm{Cr}$ (100 $\mathrm{mg} \mathrm{kg}^{-1}$ ), respectively. Similarly, the root lengths were also shortened by $16 \%$ and $24 \%$ in case of low and high $\mathrm{Cr}$ treatments, respectively. Compared to non-Cr conditions (control), the shoot and root dry weights were reduced by $25 \%$ and $33 \%$, and $28 \%$ and $50 \%$ as the result of low and high Cr exposure, respectively. The decline in biomass characteristics was more pronounced in high $\mathrm{Cr}$ stressed conditions showing that higher $\mathrm{Cr}$ stress can be lethal for growth and development. The $\mathrm{Cr}$-induced stress was 
moderated by exposure to nZVI as soil amendment and the relative biomass characteristics were improved in case of nZVI presences with $\mathrm{Cr}$ stressed conditions, compared to $\mathrm{Cr}$ alone treatments (nonnZVI). Compared to $\mathrm{Cr}$ alone, the presence of nZVI improved $17 \%$ plant height in case of low $\mathrm{Cr}$ conditions; while only 9\% increase in plant height occurred by nZVI compared to high $\mathrm{Cr}$ alone treatment. Root lengths were improved by $14 \%$ by nZVI in case of low $\mathrm{Cr}$ conditions. However, high Cr exposure along with nZVI could not improve the root lengths. The nZVI caused 19\% and 33\% increase in shoot and root dry weights in case of low Cr exposure. While nZVI amelioration of shoot and root dry weights were limited to $11 \%$ and $20 \%$ only in case of high $\mathrm{Cr}$ exposure. It can be deduced that nZVI was more effective in restoring biomass related parameters when under low Cr stress as compared to high $\mathrm{Cr}$ exposure (Figure 1).

\section{Shoot and Root Cr Concentration}

Tissue $\mathrm{Cr}$ concentrations have been shown in Figure 2. Cr concentration mainly contained in roots, however a reasonable amount was also transferred to aboveground portion. In shoots $\mathrm{Cr}$ concentration reached to $36 \mathrm{mg} \mathrm{kg}^{-1}$ and $49 \mathrm{mg} \mathrm{kg}^{-1} \mathrm{DW}$ in low and high $\mathrm{Cr}$ treatments. However, nZVI presence significantly lowered shoot $\mathrm{Cr}$ by $35 \%$ and $9 \%$ in 10 and $100 \mathrm{mg} \mathrm{kg}^{-1} \mathrm{Cr}$ exposure, respectively. Similarly, root $\mathrm{Cr}$ concentration reached upto $62 \mathrm{mg} \mathrm{kg}^{-1} \mathrm{DW}$ and $129 \mathrm{mg} \mathrm{kg}^{-1} \mathrm{DW}$ in low and high $\mathrm{Cr}$ treatments. The nZVI effectively lowered root $\mathrm{Cr}$ concentration by $6 \%$ in low and $29 \%$ in high $\mathrm{Cr}$ conditions, respectively. The results indicate that nZVI was more effective in lowering shoot $\mathrm{Cr}$ concentration in case of low $\mathrm{Cr}$ exposure; while it gave more pronounced results in terms of root $\mathrm{Cr}$ concentration under high stressed conditions.

\section{Effect of nZVI on Chlorophyll and Carotenoids Contents of Tomato Leaves under Cr Stress}

Low $\mathrm{Cr}$ stress yielded $14 \%$ and $36 \%$ decline in chlorophyll a and b contents of leaves, as compared to non-stressed control leaves. Similarly, high $\mathrm{Cr}$ stress caused $33 \%$ and 55\% decline in chlorophyll a and $\mathrm{b}$ contents in comparison with the control. nZVI markedly restore the chlorophyll a nd b contents in both low and high Cr stressed leaves. However, nZVI induced restoration of chlorophyll a and b was more pronounced in high $\mathrm{Cr}$ stressed plants (42\% and $73 \%$ ). Carotenoids contents of the leaves were also showed to decline in response to $\mathrm{Cr}$ exposure; where it was reduced to $25 \%$ and $41 \%$ compared to control, in case of low and high Cr treatments, respectively. Like chlorophyll contents, the carotenoid contents were also restored by nZVI. It was significantly improved by $17 \%$ compared to low $\mathrm{Cr}$ alone treatment. Likewise, SPAD value was laos declined by $24 \%$ and $40 \%$ by low and high $\mathrm{Cr}$, as compared to control. The nZVI improved the SPAD value by $13 \%$ in low $\mathrm{Cr}$ treatment and $40 \%$ by high $\mathrm{Cr}$ treatment. The results clearly demonstrated that nZVI was very effective in restoring plants pigmentation and carotenoids contents even in the presence of $\mathrm{Cr}$ exposure (Figure 3). 


\section{Effect of nZVI on RWC, MSI and MDA of Tomato Leaves under Cr Stress}

Cr stress negatively affected RWC and MSI of tomato leaves/shots and also induced lipid peroxidation which was evident in terms of greater production of MDA (Figure 4). Cr exposure caused wilting in plant leaves which was shown by $19 \%$ decline in RWC in low Cr treatment; while this decline was $44 \%$ in high $\mathrm{Cr}$ treatments as compared to the control plants. The nZVi caused $13 \%$ increase in RWC of low Cr treatment, while $26 \%$ increase in high Cr treatment which brough the water status to near normal conditions. Similarly, the MSI was $20 \%$ lowered by low $\mathrm{Cr}$ exposure and 35 decline in high $\mathrm{Cr}$ treatment, compared to the control plants. Again, the nZVI restored membrane stability by increasing MSI by $13 \%$ and $11 \%$ in low and high Cr treatments, respectively. The MDA content of the leaves which indicates the creation of lipid peroxidation as the result of stress, was also induced by both low and high Cr treatments. Low and high Cr treatments caused 1.6 and 2.4 times greater MDA in leaves, compared to non-stressed plants. Yet, the nZVI was effective in significantly lowering the Cr-induced MDA overproduction. nZVI produced $41 \%$ and $9 \%$ lowering of shoot MDA contents in low and high $\mathrm{Cr}$ treatments, respectively. Our results support the idea that $\mathrm{Cr}$ stressed medium causes stress indicators/biomarkers in plants while the nZVI moderated the stress indicators.

\section{Effect of nZVI on Antioxidant Enzymes in Shoots of Tomato Seedlings under Cr Stress}

Antioxidant enzyme system is the plants' internal detoxification mechanism to cope with the stressful conditions. However, stressed condition itself affects negatively this defense mechanism. Activities of antioxidant enzymes (SOD, POD, CAT and APX) have been shown in Figure 5. Generally, in our study the antioxidant enzymes activities were increase with CR exposure. However, nZVI further boosted the activities and improved the enzymatic activities combating against ROS. The SOD activity was increase by $29 \%$ and $43 \%$ by low and high Cr treatments, respectively. This enhancement was further induced by $15 \%$ and $20 \%$ by nZVI in low and high Cr treatments. The POD activity was increased by $44 \%$ and $67 \%$ by low and high Cr stress, which was further enhanced by nZVI by $56 \%$ in case of low Cr treatment. POD activity was not further increased by nZVI in case of high Cr exposure. The CAT activity was increased by 1.5 and 1.7 times the control treatment in low and high Cr treatments. This supplementation in CAT shoot activity was further boosted by nZVI by 59\% and 54\% in low and high $\mathrm{Cr}$ treatments. Similarly, the APX activity was increased by $34 \%$ and $20 \%$ in low and high $\mathrm{Cr}$ exposure, which were further induced by $25 \%$ and $64 \%$ by nZVI presence in low and high Cr conditions (Figure 5). The nZVI-induced supplementation of already enhanced antioxidant enzymes activities could further strengthen the plants intrinsic potential to cope with the environmental stresses.

\section{DISCUSSION}

$\mathrm{Cr}$ is highly toxic to living organisms including the crop plant which could severely hamper the normal growth and development. In our study, growth retardation owned to $\mathrm{Cr}$ stress has been evident 
in terms of biomass reduction. The biomass reduction was $\mathrm{Cr}$ dose dependent where $10 \mathrm{mg} \mathrm{kg}^{-1} \mathrm{Cr}(\mathrm{VI})$ exposure greatly reduced the plant height, root length and shoot and root dry biomass. This decline might be due to the plant wilting, inhibition of cell division in roots, plasmolysis and hampering of nutrients and water uptake (McCarroll et al., 2010).

Under stressful conditions, production of ROS is one of the most important indicator produced at metabolic levels that also is the case with $\mathrm{Cr}$ toxicity. We found that higher $\mathrm{Cr}$ toxicity caused greater production of MDA and also associated membrane injury in terms of lowered MSI and plant wilting as reduced percentage of RWC. These parameters were in consistency with the growth parameters indicating that MDA production, membrane injury and lowered water status caused decline in growth parameters (Ali et al., 2018). Stress creation at metabolic levels may cause injury to photosynthetic apparatus and leaves pigmentation that can lead to abnormalities in photosynthesis efficiency of the plants. Parallel with the stress indicators, chlorophyll contents, total carotenoids and the SPAD values were also badly affected by $\mathrm{Cr}$ exposure. Detoxification of the ROS by plants internal antioxidants is natural defense mechanism of the living organisms. Under normal stressed conditions, elevation of antioxidant enzymes is a normal defensive approach, which was evident in our study. The SOD, POD, CAT and APX activities in shoots were induced by sole Cr exposure. However, the nZVI presence in the soil further ensured the boosting of these enzymes. This is very interesting from the point of view of understanding the phenomenon behind nZVI induced $\mathrm{Cr}$ toxicity tolerance. One possible interpretation might be the capacity of nZVI to reduce the uptake of $\mathrm{Cr}$ from soil to roots and then further translocation to aboveground shoot tissues. Reducing the mobility might have lowered the ROS generation and other stress indicators thus moderating the Cr-induced injury. Ultimately, low stressed conditions within the plants might have boosted antioxidant system to work with its full potential and conferred the plants a great deal of resistance against $\mathrm{Cr}(\mathrm{VI})$ stress. This was further supported by overall reduction in $\mathrm{Cr}$ uptake by tomato seedlings and mainly by reduction in Cr mobility from the roots to shoots. Apparently, it seems that the soil application of nZVI has converted toxic forms of $\mathrm{Cr}(\mathrm{VI})$ into less toxic forms, $\mathrm{Cr}(\mathrm{III})$ and further reduced the uptake by roots and translocation into aboveground plant parts. Lowering of $\mathrm{Cr}$ contents in plant parts by nZVI presence in soil might have moderated the stress and further amplified the antioxidant enzymes to cope with the stress and flourish growth parameters. However, to understand the actual phenomenon involved, further studies are needed to actually specify the role of $\mathrm{Cr}$ suppression or antioxidant induction, involved behind $\mathrm{Cr}$ toxicity resistance

\section{Conclusion}

Our results demonstrate that $\mathrm{Cr}$ toxicity exerted harmful impacts on the growth of tomato seedlings, where higher Cr treatment was more detrimental in lowering plant height, root length and the biomass. The growth retardation was also accompanied with the membrane injury, leaf wilting and oxidative stress creation in terms of lowered membrane stability index, relative water content and MDA 
production. Chlorophyll contents, carotenoids contents and SPAD values were also lowered by $\mathrm{Cr}$ exposure. These stressed parameters were more pronounced in higher $\left(100 \mathrm{mg} \mathrm{kg}^{-1}\right) \mathrm{Cr}$ exposure, where shoot and root $\mathrm{Cr}$ concentrations were greatly higher than low $\mathrm{Cr}$ stress treatment. The tissue specific $\mathrm{Cr}$ concentration was mainly retained in roots. Application of $500 \mathrm{mg} \mathrm{kg}^{-1} \mathrm{nZVI}$ greatly reduced the plant injury and effectively restored growth and stressed parameters. In case of growth and biomass parameters, nZVI performed better when applied together with low $\mathrm{Cr}$ stress. However, in case of stress indicators, nZVI performance was better when applied with high $\mathrm{Cr}$ stressed conditions. Antioxidant enzymes activities were increased slightly by $\mathrm{Cr}$ exposure, but nZVI addition in the soil further boosted the activities which might have contributed greatly in conferring tolerance to $\mathrm{Cr}$ stress in tomato seedlings.

\section{REFERENCES}

Ali, S., Gill, R. A., Ulhassan, Z., Najeeb, U., Kanwar, M. K., Abid, M., Mwamba, T. M., Huang, Q., \& Zhou, W. (2018). Insights on the responses of Brassica napus cultivars against the cobalt-stress as revealed by carbon assimilation, anatomical changes and secondary metabolites. Environmental and experimental botany, 156, 183-196.

Ashraf, A., Bibi, I., Niazi, N. K., Ok, Y. S., Murtaza, G., Shahid, M., Kunhikrishnan, A., Li, D., \& Mahmood, T. (2017). Chromium (VI) sorption efficiency of acid-activated banana peel over organomontmorillonite in aqueous solutions. International journal of phytoremediation, 19(7), 605-613.

Brasili, E., Bavasso, I., Petruccelli, V., Vilardi, G., Valletta, A., Dal Bosco, C., Gentili, A., Pasqua, G., \& Di Palma, L. (2020). Remediation of hexavalent chromium contaminated water through zero-valent iron nanoparticles and effects on tomato plant growth performance. Scientific Reports, 10(1), 1920.

Cherfi, A., Achour, M., Cherfi, M., Otmani, S., \& Morsli, A. (2015). Health risk assessment of heavy metals through consumption of vegetables irrigated with reclaimed urban wastewater in Algeria. Process safety and environmental protection, 98, 245-252.

Di Palma, L., Gueye, M., \& Petrucci, E. (2015). Hexavalent chromium reduction in contaminated soil: a comparison between ferrous sulphate and nanoscale zero-valent iron. Journal of hazardous materials, $281,70-76$

Li, Z., Xu, S., Xiao, G., Qian, L., \& Song, Y. (2019). Removal of hexavalent chromium from groundwater using sodium alginate dispersed nano zero-valent iron. Journal of environmental management, 244, 33-39.

Malik, Z., Afzal, S., Dawood, M., Abbasi, G. H., Khan, M. I., Kamran, M., Zhran, M., Hayat, M. T., Aslam, M. N., \& Rafay, M. (2021). Exogenous melatonin mitigates chromium toxicity in maize seedlings by modulating antioxidant system and suppresses chromium uptake and oxidative stress. Environ Geochem Health. https://doi.org/10.1007/s10653-021-00908-z

Malik, Z., Afzal, S., Dawood, M., Abbasi, G. H., Khan, M. I., Kamran, M., Zhran, M., Hayat, M. T., Aslam, M. N., \& Rafay, M. (2021). Exogenous melatonin mitigates chromium toxicity in maize seedlings by modulating antioxidant system and suppresses chromium uptake and oxidative stress. Environmental Geochemistry and Health, 1-19. 
McCarroll, N., Keshava, N., Chen, J., Akerman, G., Kligerman, A., \& Rinde, E. (2010). An evaluation of the mode of action framework for mutagenic carcinogens case study II: chromium (VI). Environmental and molecular mutagenesis, 51(2), 89-111.

Mitra, S., Sarkar, A., \& Sen, S. (2017). Removal of chromium from industrial effluents using nanotechnology: a review. Nanotechnology for Environmental Engineering, 2(1), 1-14.

Noli, F., \& Tsamos, P. (2016). Concentration of heavy metals and trace elements in soils, waters and vegetables and assessment of health risk in the vicinity of a lignite-fired power plant. Science of the Total Environment, 563, 377-385.

Oh, Y. J., Song, H., Shin, W. S., Choi, S. J., \& Kim, Y.-H. (2007). Effect of amorphous silica and silica sand on removal of chromium (VI) by zero-valent iron. Chemosphere, 66(5), 858-865.

Patra, D. K., Pradhan, C., \& Patra, H. K. (2019). Chromium bioaccumulation, oxidative stress metabolism and oil content in lemon grass Cymbopogon flexuosus (Nees ex Steud.) W. Watson grown in chromium rich over burden soil of Sukinda chromite mine, India. Chemosphere, 218, 1082-1088.

Shaheen, N., Irfan, N. M., Khan, I. N., Islam, S., Islam, M. S., \& Ahmed, M. K. (2016). Presence of heavy metals in fruits and vegetables: Health risk implications in Bangladesh. Chemosphere, 152, 431-438.

Singh, D., Sharma, N. L., Singh, C. K., Sarkar, S. K., Singh, I., \& Dotaniya, M. L. (2020). Effect of chromium (VI) toxicity on morpho-physiological characteristics, yield, and yield components of two chickpea (Cicer arietinum L.) varieties. PloS one, 15(12), e0243032.

Singh, D., Sharma, N. L., Singh, C. K., Yerramilli, V., Narayan, R., Sarkar, S. K., \& Singh, I. (2021). Chromium (VI)-Induced Alterations in Physio-Chemical Parameters, Yield, and Yield Characteristics in Two Cultivars of Mungbean (Vigna radiata L.) [Original Research]. Frontiers in Plant Science, 12(2059). https://doi.org/10.3389/fpls.2021.735129

Vilardi, G., Di Palma, L., \& Verdone, N. (2019). A physical-based interpretation of mechanism and kinetics of $\mathrm{Cr}(\mathrm{VI})$ reduction in aqueous solution by zero-valent iron nanoparticles. Chemosphere, 220, 590599.

Vilardi, G., Sebastiani, D., Miliziano, S., Verdone, N., \& Di Palma, L. (2018). Heterogeneous nZVI-induced Fenton oxidation process to enhance biodegradability of excavation by-products. Chemical Engineering Journal, 335, 309-320.

Wakeel, A., Xu, M., \& Gan, Y. (2020). Chromium-induced reactive oxygen species accumulation by altering the enzymatic antioxidant system and associated cytotoxic, genotoxic, ultrastructural, and photosynthetic changes in plants. International journal of molecular sciences, 21(3), 728.

Yu, X.-Z., Lu, C.-J., \& Li, Y.-H. (2018). Role of cytochrome c in modulating chromium-induced oxidative stress in Oryza sativa. Environmental Science and Pollution Research, 25(27), 27639-27649.

Yuvakkumar, R., Elango, V., Rajendran, V., \& Kannan, N. (2011). Preparation and characterization of zero valent iron nanoparticles. Digest journal of nanomaterials and biostructures, 6(4), 1771-1776.

Zaheer, I. E., Ali, S., Saleem, M. H., Imran, M., Alnusairi, G. S., Alharbi, B. M., Riaz, M., Abbas, Z., Rizwan, M., \& Soliman, M. H. (2020). Role of iron-lysine on morpho-physiological traits and combating chromium toxicity in rapeseed (Brassica napus L.) plants irrigated with different levels of tannery wastewater. Plant Physiology and Biochemistry, 155, 70-84. 
Zeng, F., Zhou, W., Qiu, B., Ali, S., Wu, F., \& Zhang, G. (2011). Subcellular distribution and chemical forms of chromium in rice plants suffering from different levels of chromium toxicity. Journal of Plant Nutrition and Soil Science, 174(2), 249-256. 


\section{FIGURES}
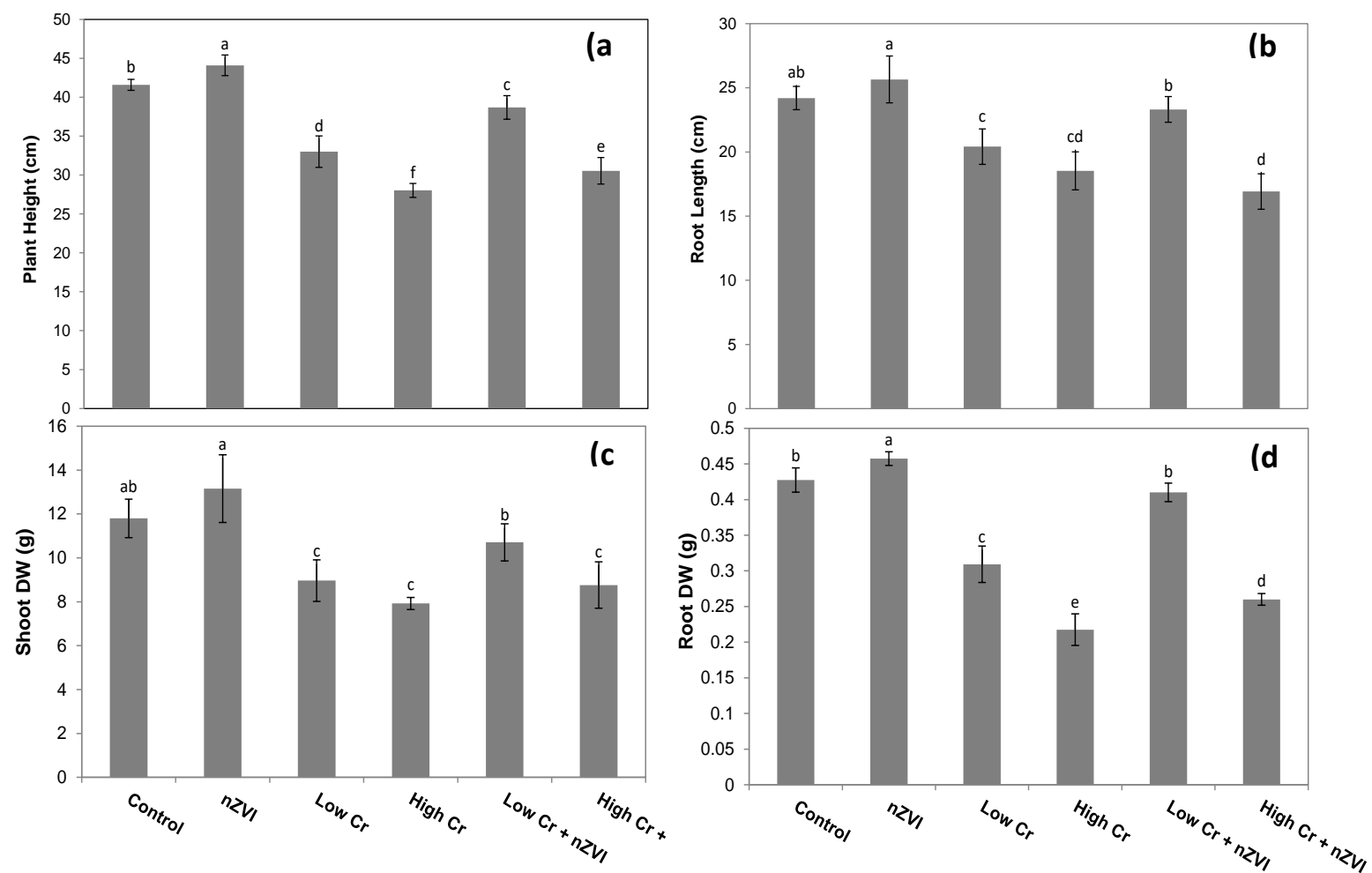

Figure 1. Effect of solo and combined application of nZVI and $\mathrm{Cr}$ on biomass (plant height (a); root length (b); shoot dry weight (c); root dry weight (d)) of tomato seedlings. Individual bars represent treatment means \pm standard deviation $(n=3)$. Treatment means not sharing a common letter are significantly different from each other $(p \leq 0.05)$.
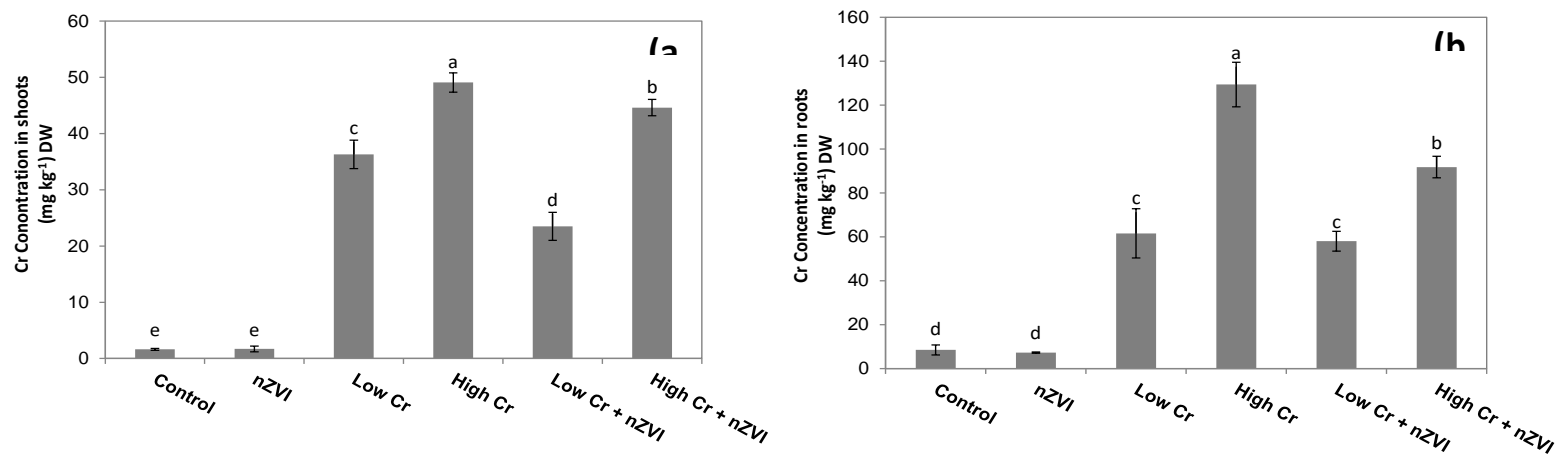

Figure 2. Effect of solo and combined application of nZVI and $\mathrm{Cr}$ on $\mathrm{Cr}$ concentration in shoots (a) and roots (b) of tomato seedlings. Individual bars represent treatment means \pm standard deviation $(n=3)$. 

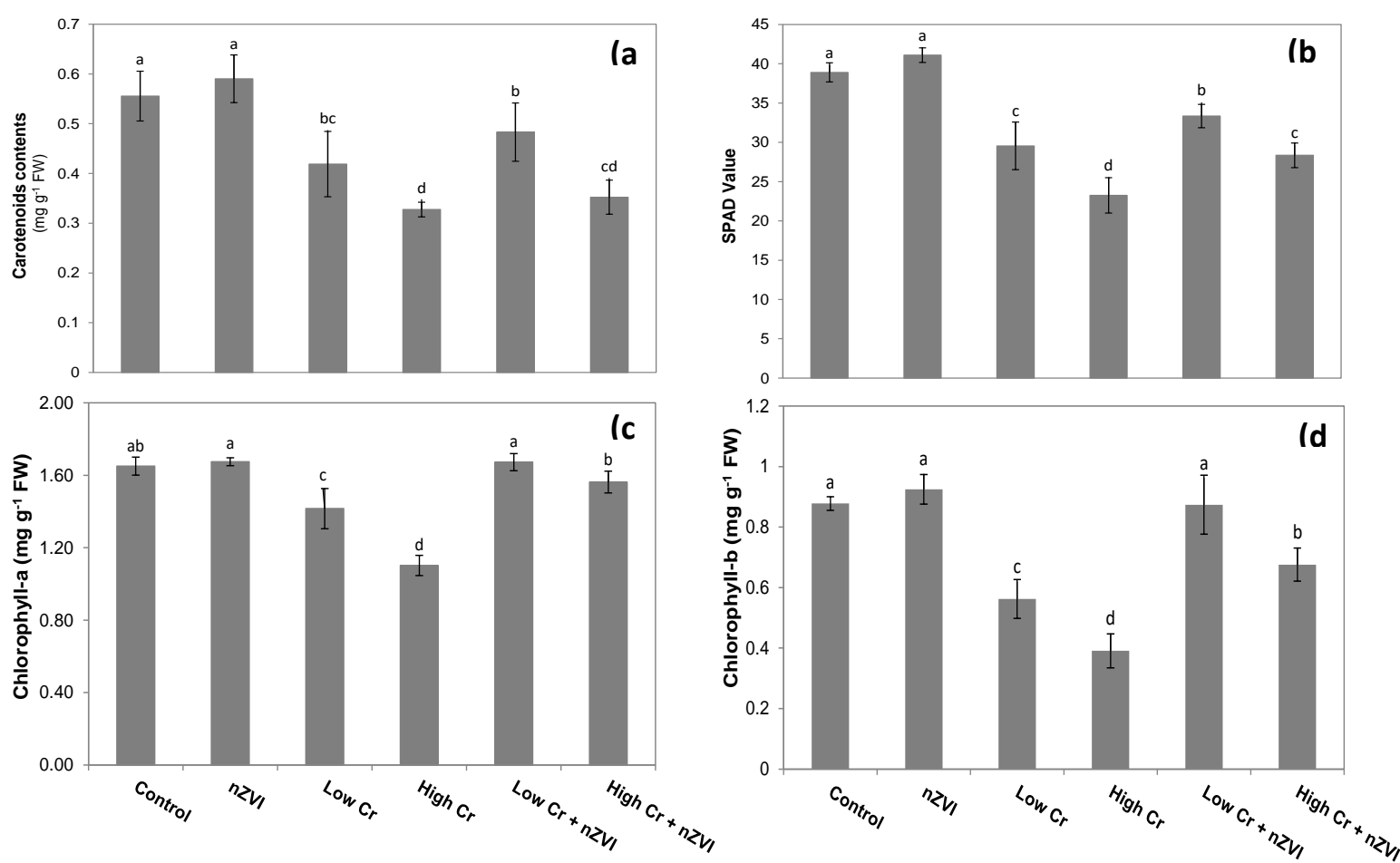

Figure 3. Effect of solo and combined application of nZVI and $\mathrm{Cr}$ on carotenoid contents (a), SPAD value (b), chlorophyll-a (c) and chlorophyll-b (d) of tomato seedlings. Individual bars represent treatment means \pm standard deviation $(\mathrm{n}=3)$. Treatment means not sharing a common letter are significantly different from each other $(\mathrm{p} \leq 0.05)$.
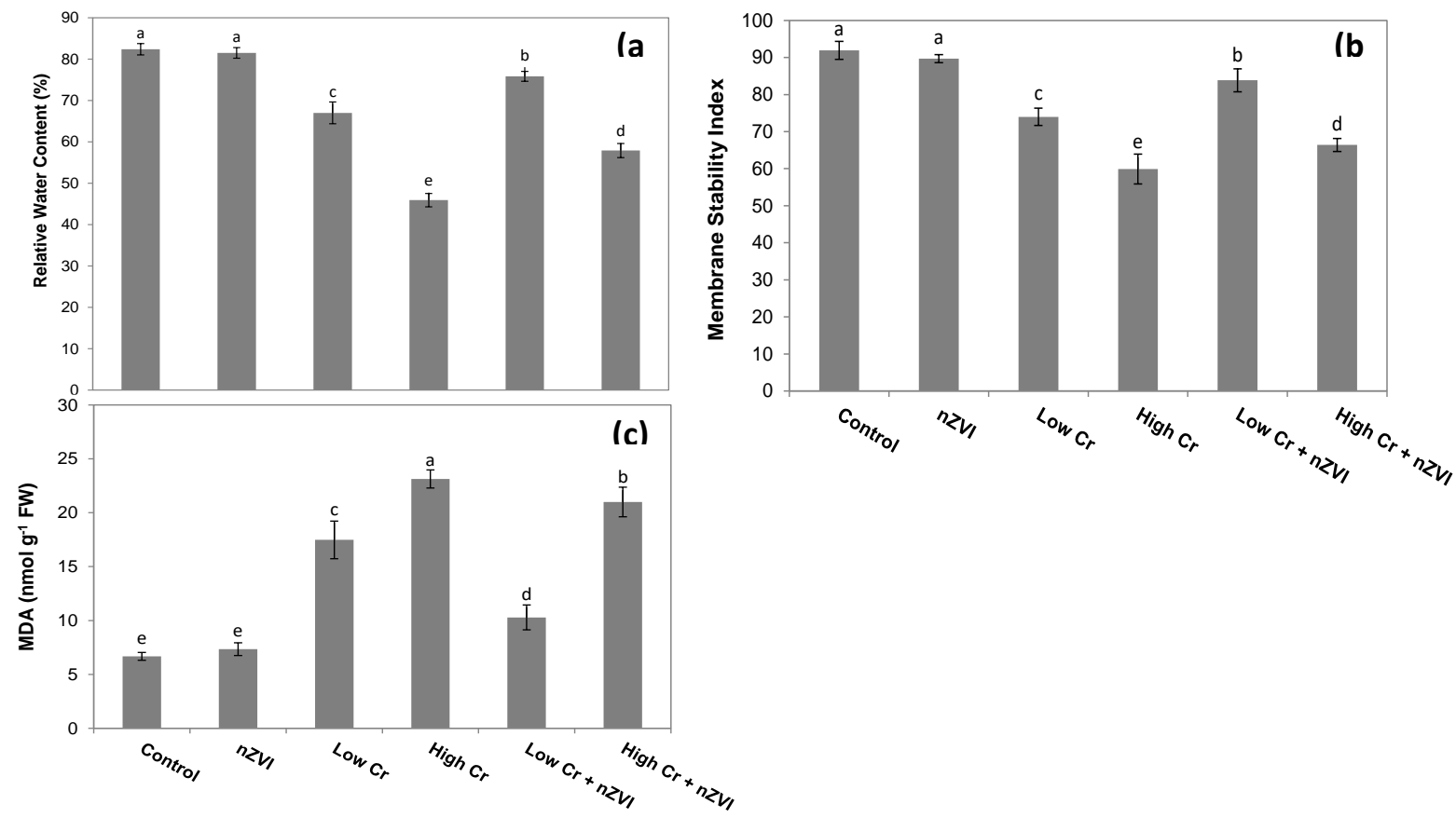

Figure 4. Effect of solo and combined application of nZVI and $\mathrm{Cr}$ on relative water content (a), membrane stability index (b) and MDA content (c) of tomato seedlings. Individual bars represent treatment means \pm standard deviation $(n=3)$. Treatment means not sharing a common letter are significantly different from each other $(p \leq 0.05)$. 

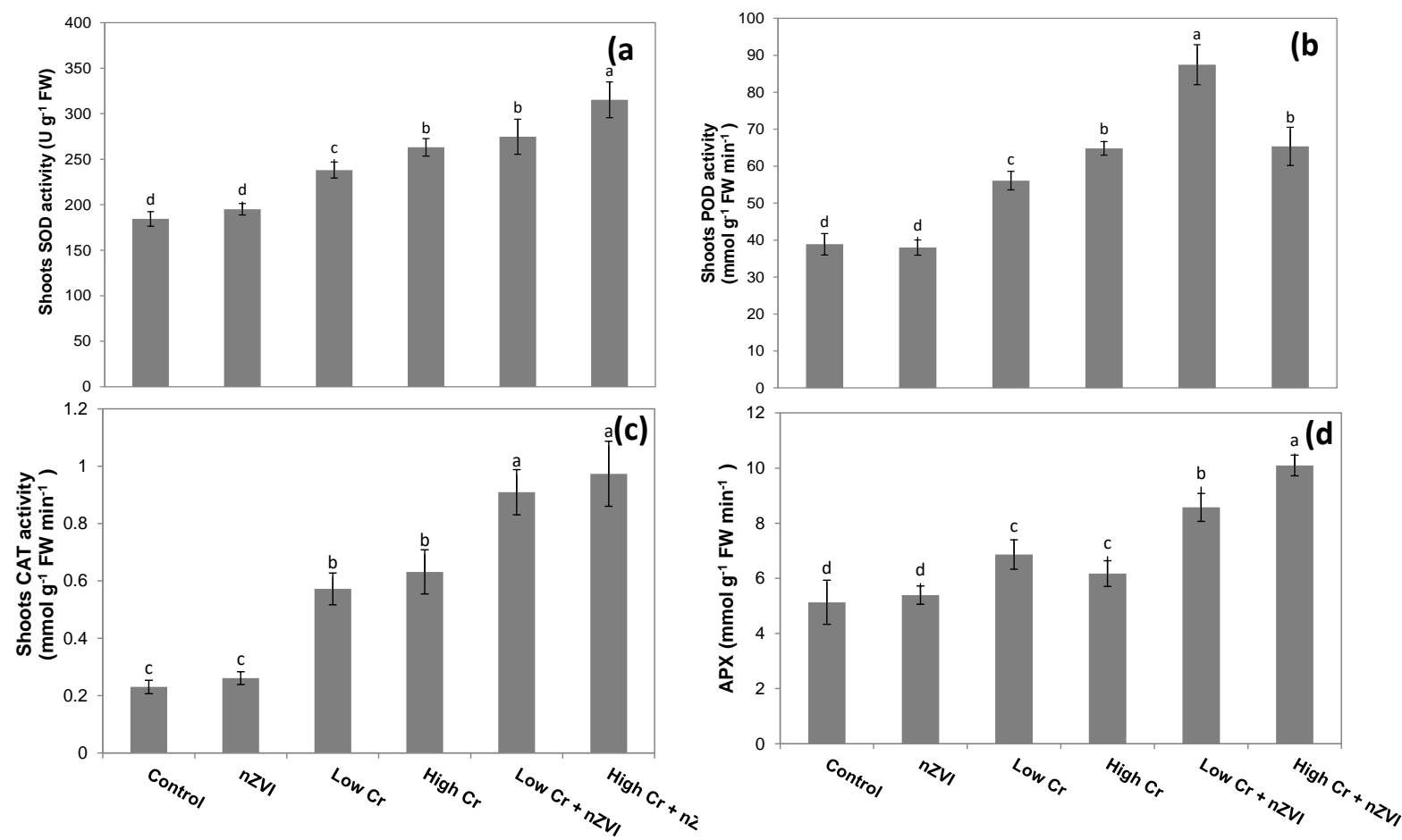

Figure 5. Effect of solo and combined application of nZVI and $\mathrm{Cr}$ on antioxidant enzyme activities in shoots (SOD activity (a), POD activity (b), CAT activity (c) and APX activity (d) of tomato seedlings. Individual bars represent treatment means \pm standard deviation $(n=3)$. Treatment means not sharing a common letter are significantly different from each other $(p \leq 0.05)$. 